\title{
А.В.СКИПЕРСКИХ \\ ГОРОД ЕЛЕЦ В РЕГИОНАЛЬНОМ КУЛЬТУРНОМ ПРОСТРАНСТВЕ: ПРОВИНЦИЯ ИЛИ ЦЕНТР?
}

Скиперских Александр Владимирович, доктор политических наук, профессор кафедры философии и социальных наук Елецкого государственного университета им. И.А. Бунина; Российская Федерация, 399770, Елец, ул. Коммунаров, д. 28 , тел.: +7 4746722193

E-mail: pisatels@mail.ru

В данной статье автор пытается дать оценку возможностям города Ельца выступать в качестве культурного центра Липецкой области. С одной стороны, статус Города воинской славы, имеющего к тому же богатую культурную и промышленную историю, как будто располагает к этому. В пользу этого говорит присутствие города в дискурсе интеллектуальной истории и значимых текстах отечественной и мировой культуры. С другой стороны, ряд факторов могут существенно затруднить подобное позиционирование городского пространства, опрощая его, понижая его возможности и превращая в обыкновенную провинцию. Здесь невольно играет роль и соперничество за туристические потоки с Липецком, постепенно актуализирующееся в условиях новой экономической реальности, когда именно культура оказывается ключевым драйвером развития.

В исследовании используется метод дискурс-анализа, позволяющий определить специфику бытования концепта «центр» у тех или иных субъектов городской политики. С помощью данного метода автор пытается дать оценку культурному потенциалу г. Ельца. Цель исследования - акценты, субъекты и проблемные локусы культурной политики городской власти, прямо связанные с конструированием образа города как культурного центра Липецкой области.

Ключевые слова: дискурс; Елец; культурная политика; Липецкая область; провинция; пространство; центр.

Цитирование: Скиперских А.В. (2019) Город Елец в региональном культурном пространстве: провинция или центр? //Городские исследования и практики. Т. 4. № 3. C. 71-88. DOI: https://doi.org/10.17323/usp43201971-88

$\mathrm{B}$

2019 году отмечался 65-летний юбилей Липецкой области. Праздничные события, посвященные годовщине ее образования, пришлись как раз на смену губернатора. Вместо Олега Королева, управлявшего Липецкой областью более двадцати лет, был назначен Игорь Артамонов, ранее работавший в руководстве Сбербанка. Юбилейные события преподносились широко, преимущественно «сверху», и отмечались в большей степени в самом Липецке. В других муниципальных центрах интерес к юбилею был менее заметен.

Липецкая область была создана в 1954 году в результате административной реформы. Изначально акценты были расставлены так: хотя Липецк являлся областной столицей в советский период и является столицей субъекта РФ сегодня, представляет собой промышленный город - важный центр российской металлургии. Внимание к культурному топосу было на втором плане. Куда важнее было решать вопросы, связанные с той же социальной политикой, ведь быстрый рост городского населения и накопление трудовых ресурсов за счет провинции требовали быстрых решений в сфере социальной инфраструктуры (больницы, поликлиники, школы, детские сады и т.д.). Развитие культурного слоя при этом оставалось вторичным - воспоминания о выдающихся событиях прошлого и апелляции к городскому тексту известных земляков не выступали значимыми элементами новой исторической конструкции. При этом эксплуатация культурного слоя становилась уделом липецкой периферии.

В нашем исследовании будет рассмотрена ситуация конструирования культурного центра Липецкой области применительно к городу Ельцу. 


\section{Елец как культурный центр: концептологические изыскания}

В системе нового административного деления Елец обладает значимым историко-культурным бэкграундом. Второй по численности населения город Липецкой области ранее входил в Орловскую губернию и имел шансы стать губернским городом, если бы несколько иначе сложилась политическая конъюнктура. Именно Елец вплоть до сегодняшнего дня может рассматриваться как культурный центр региона, хотя некоторые практики городской политики могут постепенно поставить под сомнение этот неформальный статус.

Ситуация конструирования культурного центра в Липецкой области может быть определена как «драматургия публичного представления, процесс изготовления публичной сферы» [Мальковская, 2004, с. 17]. Нужно отметить, что в условиях постмодерна центр вообще очень сложно устанавливается, особенно если речь идет о сложных социальных организациях.

Любой концепт испытывает постоянное искушение быть растянутым и измененным за счет добавления новых значений и оттенков смыслов, как отмечал итальянский исследователь Джованни Сартори [Сартори, 2003, с. 153]. Дискурс постоянно расширяется, что делает любые попытки рассмотрения его отдельных элементов слишком затруднительными ${ }^{1}$.

Дискурс-анализ предполагает и другие ограничения и умолчания. В частности, это и определяет Ролан Барт, говоря, что везде будет присутствовать власть, «гнездящаяся в любом дискурсе» [Барт, 1989, с. 547]. Действительно, любые попытки говорить о «центре» неизбежно будут захватывать сферу политического, где власть всегда в середине. Город «схватывается» властью, а интересы политической элиты всегда превалируют над потребностями городского населения.

Следует вспомнить и о теоретических изысканиях Харви Молотча, который, рассматривая город в интересующем нас контексте, использовал метафору «машины роста и развития» [Molotch, 1976]. При этом политическая элита максимизирует прибыль, буквально выжимая ее из города. Поэтому любая инициатива власти, на первый взгляд кажущаяся вполне себе благовидной, на самом деле может иметь вполне прозаические мотивы получения прибыли ограниченным кругом лиц, стремящихся осваивать городские публичные пространства и красочно представлять их будущее с помощью лояльных медиа. Сегодня вместо позитивных реляций печатных СМИ преимущества новых трендов городского развития часто представляют специально обученные люди, показывая эффектные презентации. В принципе, ситуация сходна с описываемыми американским социологом 1970-ми годами. По-прежнему за внешним преображением города скрываются узкоэгоистические интересы меньшинства - представителей политического класса, подрядчиков, кураторов подрядчиков и т. д. Действительно, как отмечает Молотч, росту подвержена только «небольшая часть резидентов отдельного локуса», при этом после такого роста остаются огромные инфраструктурные проблемы [Molotch, 1976, p. 318]. Справедливость гипотезы Молотча очевидно раскрывается на примере Ельца. В городском тексте есть масса свидетельств того, как действующая на тот или иной момент времени правящая элита оставляла после себя следы своего политического доминирования и как это затрагивало культурный слой города. Открытие новых торговых центров, закладные камни виртуальных микрорайонов, широкий фронт работ по благоустройству - все это, осуществлявшееся в интересах легитимации городской администрации, безусловно, оттеняло культурный бэкграунд. Появление очередного новодела означало утрату очередного исторического особняка в центре города. В этом плане инициативы власти по благоустройству, по созданию новых общественных пространств, необычных для провинции малых архитектурных форм могут восприниматься достаточно неоднозначно.

В других «неполитических» исследовательских метриках центр будет постоянно ускользать от четкого определения и достаточно проблемно концептуализироваться. Применительно к исследованиям регионального культурного ландшафта могут существовать различные позиции, «определяющие оптику и угол зрения» [Богомяков, 1997, с. 5]. Решающим оказывается оптика самого субъекта, определяющего границы центра. В случае Ельца достаточно показа-

1 В рамках нашего исследования дискурс-анализ поглощает другие методологические инструменты и кажется наиболее оптимальным. Попытки излишней детализации, концентрации на конкретных кейсах будут уводить нас от максимально широкой оценки претензий Ельца на право позиционироваться культурным центром. Таким искушением могло бы стать определение Ельца как публичного пространства, что потребовало бы подключения к анализу целого пласта исследований публичной сферы и ее политического определения (Х. Арендт, Ю. Хабермас, Р. Сеннет и др.). 
тельно данная концептуализация срабатывала в период новогодних праздников 2020 года. Городская администрация при поддержке предпринимателей усиленно занялась украшением площади Ленина и пешеходной улицы Мира. На городском фонтане был смонтирован лайтбокс, устроена иллюминация на исторической башне - городских курантах ${ }^{2}$.

В центре может присутствовать и другой центр - любое пространство может быть бесконечно делимым.

\section{Елецкий текст и его жизненные формы}

Попытки определения Ельца как регионального и культурного центра можно встретить у различных исследователей, видевших город в качестве средоточия интеллектуальных сил. Формы бытования елецкого текста достаточно вариативны.

Культурный бэкграунд провинциального Ельца - это особый мир классического университета, в период своего расцвета приглашавшего профессуру из теперь уже бывших союзных республик. В частности, совсем недавно на корпусах ЕГУ им. И.А. Бунина появились несколько баннеров в честь 100-летия университета. Билборды напоминают, что университет основан первым среди остальных вузов области ${ }^{3}$.

Елец к тому же и театральный город - здесь еще с первой половины XIX века существовал драматический театр, который возродился, приняв после распада СССР театральный коллектив из Алма-Аты. Елец - важный центр и художественного искусства.

Отнесение Ельца к театральной провинции встречается у А.П. Чехова в реплике Нины Заречной. Известны очерки о Ельце и В. Немировича-Данченко, описывающего елецкую реальность в драматургической тональности А. Островского, где новые, прогрессивные люди сопротивляются «темным» консерваторам - Дикому и Кабанихе. Наконец, с именем Т. Хренникова связывается особый культурный функционал Ельца как центра музыкальной культуры и истории, сумевшего организовать конвергенцию «потоков разной силы - от центра - к провинции, от провинции - к провинции, от центра - к иному центру» [Тулинова, 2012, c. 107]. Сложно не согласиться с точкой зрения некоторых авторов, что в целом «столичная музыкальная культура подпитывалась провинциальными силами» [Тулинова, 2012, с. 107].

Важным импульсом в развитии культурного дискурса города могло бы стать Елецкое художественное училище (прекратило существование в 1957 г.). В воспоминаниях его выпускников тех лет слышится недоумение: «1957 год - начало хрущевской оттепели. В училище жизнь бьет ключом. Появляется интерес к тому, что было под запретом» [Широков, 1994, с. 12]. Однако решение властей могло иметь вполне резонные по тем временам причины ${ }^{4}$.

Особая притягательность Ельца в споре за право считаться культурным центром липецкого края может скрываться и в коллекции Елецкой художественной галереи. В частности, неожиданными «фишками», открывающимися для ценителей, могут стать работы представителей русского авангарда - Л. Пастернака, В. Рождественского, О. Розановой, Н. Синезубова, Н. Ульянова, не говоря уже о некоторых шедеврах русской реалистической живописи.

Неоднократно Елец появляется и в художественных фильмах. Несложно догадаться, чем город мог пленять кинорежиссеров. Винтажная фактура привлекает мастеров интеллектуального кино. В частности, в 1980-х годах в Ельце снимался фильм «Бесконечность» (1991) Марлена Хуциева и фильм «Мальчики» (1990) по мотивам одной из глав романа «Братья Карамазовы» Ф. Достоевского (реж. Юрий и Ренита Григорьевы).

Статус культурного центра Липецкой области может легко обрести и формальные основания. По данным Государственной дирекции по охране культурного наследия Липецкой области, на настоящий момент времени в регионе находится 602 памятника и объекта, представляющих культурную ценность. При этом в Ельце насчитывается 202 таких памятника и объекта, что со-

2 В период новогодних каникул в центре города отмечался небывалый ажиотаж. Вместе с тем вся энергия благоустройства была стянута именно к центру, в то время как периферийные районы города оставались в полумраке.

3 На этом примере можно увидеть соперничество Ельца и Липецка в качестве интеллектуального и культурного центра. 100-летний юбилей вуза является более чем приблизительным. Реальной точкой отсчета университетской истории выступает 2000 год, когда вуз обрел данный официальный статус.

4 Неформальное значение художественного училища в жизни елецких интеллектуалов того времени было велико. Для понимания техники иконописи начинали копировать иконы в рамках тайно созданной секции древнерусской живописи. Более подробно об этой истории - [Широков, 1994]. 
ставляет больше трети всего количества. Для сравнения: в Липецке таких памятников и объектов находится только 54 (около 9\%) 5 . Говоря о центре, важно понимать, с какими качествами он должен быть связан и что именно представлять в избытке. В этом смысле роль православного паломнического центра Липецкой области принадлежит Задонску, в котором находится 34 памятника и объекта, представляющих культурную ценность 6 . Маленькие городки Липецкой области - Данков, Задонск, Чаплыгин - сегодня являются своеобразными городами-музеями, что говорит об особой логике развития самих муниципалитетов и практиках управления ими.

Для российских исследователей уже не является откровением мысль о том, что «социальноэкономическое положение действует депривирующим образом на возможности активизации политической жизни в современной России. Для конституирования городского политического пространства очевидно не хватает ресурсов» [Дука, 2016, с. 12]. Следует ли из этого утверждения вывод о том, что ресурсов не хватает и на культурную политику, в связи с чем она вынуждена профанировать и удешевляться? Производство культуры «сверху» все чаще происходит в спектакулярных формах, удовлетворяющих не слишком взыскательную аудиторию провинции. Подобные посылы можно найти у Ги Дебора [Дебор, 2011].

На примере разбираемого нами кейса местной политики так и происходит. Ее брендирование и зависимость от культурной и исторической специфики уже попадала в исследовательский фокус. На политику идентичности могут оказывать влияние авторитетные личности, литературные классики и интеллектуалы, воспевавшие genius loci в своих текстах. Применительно практически к каждому региону можно найти попытки дискуссий о культурном капитале, раскрываемые в тех или иных научных текстах. В частности, говоря о таких исследованиях, следует отметить работы о Екатеринбурге - Н. Журавлевой и С. Мельниковой [Журавлева, Мельникова, 2016], Перми - В. Абашева [Абашев, 2000], Тюмени - В. Богомякова [Богомяков, 2007].

Что касается Липецкой области, следует отметить явный дефицит научных заявок на изучение культурных оснований местной идентичности и центрирующих ее агрегаций. Вместе с тем есть многочисленные краеведческие изыскания и исторические интерпретации, в которых объектами авторского научного интереса выступают монастыри, храмы, усадьбы, биографии знаменитостей, промышленная история и т.д.

Применительно к Ельцу следует обратить внимание на ряд исследований, непосредственно посвященных его уникальному культурному тексту. Это могут быть исторические и статистические справки о Ельце, раскрывающие особенности его торговли и промышленности, состояния финансовых и деловых кругов. В частности, к числу таких текстов принадлежат материалы Н.А. Ридингера [Ридингер, 1993].

Характерной чертой городского этнопейзажа является высокая концентрация объектов религиозной архитектуры. Безусловно, уже в этом можно увидеть определенную претензию быть признанным культурным центром. Подробное исследование городских храмов и монастырей можно увидеть у А. Клокова, А. Найденова и А. Новосельцева [Клоков, Найденов, Новосельцев, 2006].

Елец представляется важным хронотопом в жизни известных интеллектуалов, внесших вклад в русскую и мировую культуру. Исследования биографий и особой роли города в их становлении и развитии составляет еще один массив текстов о Ельце. К их числу следует отнести работы А. Дмитриева об И. Бунине [Дмитриев, 2007] и Н. Кистеревой и В. Резвого о М. Касаткине [Кистерева, Резвый, 2017]. Конечно же, интеллектуальный ландшафт Ельца не ограничивается указанными фигурами. Здесь помимо них М. Пришвин, В. Розанов, Н. Семашко, Т. Хренников, Иннокентий Херсонский и о. Исаакий (Виноградов). Значительный вклад в культурный капитал города внесла семья Стаховичей.

Все вместе взятое может представлять собой особый феномен Ельца - оплота русской культуры, духовного и культурного центра, защитника рубежей и крепости, который представляет-

5 Все объекты и памятники Липецкой области доступны на ресурсе: Памятники архитектуры Липецкой области. Город Елец: http://cultura48.ru/?s=\&mosregion=10\&age=0 \&arch=0.

6 В дискурсе паломнического туризма безусловным центром Липецкой области является Задонск, концентрирующий в себе мощный пласт религиозной культуры, по сути, сам по себе являющийся городом - храмом и монастырем, вдобавок удобно расположенный на федеральной трассе.

Все объекты и памятники Липецкой области доступны на ресурсе: Памятники архитектуры Липецкой области. Город Задонск: http://cultura48.ru/?s=\&mosregion=10 \&age=0 \&arch=0. 
ся в тексте собеседника Михаила Бахтина - известного советского интеллектуала Владимира Турбина [Турбин, 1967].

Вместе с тем актуальность комплексного исследования культурного капитала отдельно взятого локуса Липецкой области, а в нашем случае города Ельца, не вызывает сомнений. Суммируя опыт административной сепарации Липецкой области, невольно возникает вопрос, насколько за данный период времени была проработана региональная культурная идентичность и на каких важных схемах, персоналиях и сюжетах она может базироваться? Отсутствие каких-либо глубоких исследований культурного ландшафта Липецкой области, несомненно, говорит об определенной актуальности попыток разобраться в вопросах липецкой культурной идентичности и ее основных составляющих элементах.

Культурное пространство периферийных муниципалитетов в Липецкой области чрезвычайно истощено. Оно может периодически наполняться посредством мобилизационных форм социальной активности. Когда сложно показать эффективность в промышленном и экономическом росте, власть пытается изобразить достижения в культуре, подчеркивая свою неустанную заботу о воспитании особой чувствительности к конкретному локусу и его выдающимся субъектам.

Сегодня едва ли не каждая сельская администрация проводит свои гастрономические мероприятия, активно посещаемые как администрацией муниципалитетов, так и областной властью. Получается достаточно привлекательная картинка, моментально заполняющая социальные сети и электронные медиа, - у чиновников есть доказательства проведенного мероприятия, а стало быть, и собственной эффективности. Данные мероприятия и фестивали постепенно фиксируют изобретенную властью традицию. Это может являться еще одним доказательством того, что липецкая периферия в смысле разнообразия культурной жизни определенным образом противопоставляется серым будням металлургического Липецка. В частности, из 33 событийных мероприятий, организуемых в Липецкой области в 2019 году, только шесть проводятся в самом Липецке

О всплесках культурной жизни на периферии можно говорить и в случае различных практик коммеморации, когда в публичных пространствах провинции начинают вспоминать о минувшем. Практики открытия мемориальных досок, в частности в Ельце, уже становились объектом нашего исследовательского интереса, но и в данном случае ключевым субъектом коммеморации выступает сама власть [Скиперских, 2017, с. 126]. Безусловно, данные мероприятия говорят о попытках власти нарастить культурный текст, повлиять на его неуловимый и капризный гений. Правда, сложно спрогнозировать, насколько эта политика является адекватной общественным запросам. Стоит ли благодарить власть за такие жесты в условиях, когда само существование людей сведено к элементарному выживанию? Складывается ситуация, когда после улетучивания праздничной эйфории возведенный объект и само послание «остается один на один со зрителем» [Манин, 1999, с. 36].

Вместе с тем нет никаких сомнений в том, что власть пытается подстроить прошлое под текущую конъюнктуру, где именно она будет выступать ключевым интерпретатором и ньюсмейкером.

\section{Новые акценты коммеморации}

Борьба за право называться культурной столицей Липецкой области требует не только поддержания культурного пространства в адекватном состоянии, но и производства новых мифов. Областная власть все еще находится в поиске бренда региона и более или менее четкого представления о том, с чем должна связываться липецкая идентичность. В полной мере это имеет отношение и к Ельцу.

Акценты коммеморации постоянно меняются. В 1990-2000-х годах было ощущение, что брендирование городского пространства не может состояться без связи с творческим наследием Ивана Бунина, именем которого был назван активно развивавшийся университет. Тогда не было сомнений в том, что городской текст должен конструироваться под аккомпанирование «мелодичного перестукивания коклюшек» известных на весь мир елецких кружевниц [Краснова, 2008, c. 74]. При этом знаковым должно быть начало осени - время сбора антоновских яблок.

7 Подробнее об этом см.: [Липецкая земля..., 2019]. 
Ситуация менялась с политической конъюнктурой. Технократический имидж Игоря Артамонова, нового губернатора Липецкой области, означал для региональных чиновников перезагрузку культурного дискурса региона в пользу экономических акцентов. Вопрос эффективности для новой липецкой элиты становится принципиальным. Сегодня власть подтверждает это в своих откровениях. Именно об этом реплика бывшего заместителя главы администрации Липецкой области Ю. Тарана, как-то осознавшего, что «просто фестивалями огурца, сала, лука, яблок никого не удивишь» [Завалипина, Литаврин, 2019, с. 2].

Длительный процесс конструирования советской идентичности привел к формированию в культурном пространстве Липецкой области твердой памяти о тех или иных важных событиях и героях, связанных с периодом становления и развития советской государственности. Отказ от советской героики сегодня в полной мере прослеживается не только на федеральном уровне, но и в отдельно взятых субъектах РФ и муниципалитетах. Теперь в интересах городской власти культурный текст Ельца должен связываться с новыми фигурами. Но, как зачастую происходит в России, акценты коммеморации связываются не с гражданской активностью «снизу», стремящейся закрепить благородную миссию своего пространства обитания, а, наоборот, выступают свидетельством бюрократической вкусовщины и эстетической претензии правящего класса.

В Ельце заметен патриотический бум, проецируемый и на культурную политику. Помимо мемориальных досок открываются новые мемориальные пространства, закрепляющие в общественном сознании героику конкретных исторических событий и персоналий. За последние несколько лет в Ельце произошло существенное пополнение мемориала воинам-афганцам, где устанавливается военная техника. Был даже доставлен вертолет Ми-24. Бывший глава Ельца С. Панов всячески подчеркивал свое армейское прошлое в ВДВ, поэтому мемориал находился под его особой заботой. В дискурсе городской политики есть устойчивое восприятие сквера воинов-интернационалистов как памятного места, где проходит множество городских военно-патриотических мероприятий, что по-своему обосновало для Министерства обороны РФ поддержку данной инициативы городской администрации.

Необходимость создания новых мифов, подчеркивающих связь с Ельцом выдающихся фигур русской и советской истории, заставляет власть открывать новые памятники. Данный процесс происходит начиная с 1990-х годов и до настоящего времени ${ }^{8}$. Представители правящего класса постоянно испытывают необходимость в красивой и эффектной картинке с перерезанием красной ленточки, следуя, как отмечал Э. Неизвестный, четко установленному иерархическому протоколу. При этом оказывается куда более важным, «кто открывает работу, нежели, как сделано» [Неизвестный, 1991, с. 36].

Четко установленную последовательность действий власти при производстве практик коммеморации А. Ассман называла «хореографией», правда, с не слишком завидными последствиями для легитимности самой власти, порождающими вполне закономерное недовольство и даже отвращение [Ассман, 2016].

Акцент городской власти на открытие новые мемориальных пространств очевиден. Открыть мемориальную доску или памятник для городской администрации сегодня намного проще, чем запустить производство, обеспечивающее работой горожан, либо сделать более совершенным качество городской инфраструктуры.

Так, в конце июля 2016 года в Комсомольском сквере Ельца был открыт памятник легендарному командующему ВДВ В. Маргелову, предваряющий череду коммеморативных жестов памяти Героя СССР в других городах России. Открытие памятника имеет и вполне конкретный легитимационный эффект, ведь в сообществе десантников в Ельце состоят более тысячи человек9.

При этом связь В. Маргелова с Ельцом не представляется очевидной и подтвержденной конкретными источниками. Тем не менее городская власть посылает вовне четкий сигнал о том, какие именно акценты культурной политики присутствуют сегодня в Ельце как Городе воинской славы. Не представляется очевидной и связь с Ельцом героя Отечественной войны

8 Начиная с 1990-х годов в Ельце появляются памятники И. Бунину, М. Пришвину, Елецкому пехотному полку, памятные стелы и т.д. Инициатива здесь принадлежит не только власти, но и общественности. Например, на территории одной из галерей, принадлежащей известному елецкому галеристу и коллекционеру Евгению Крикунову, был установлен памятник русскому религиозному философу Василию Розанову.

9 Подробнее о церемонии открытия памятника В. Маргелову в Ельце см.: Памятник легендарному Василию Маргелову торжественно открыли в Ельце, 25.07.2016/ГТРК «Липецк»: http://vesti-lipetsk.ru/pamyatnik-legendarnomu-vasiliyu-margelovu-torzhestvenno-otkryli-v-elce/. 
1812 года генерала М. Милорадовича, памятник которому был открыт рядом с памятником В. Маргелову в начале сентября 2018 года ${ }^{10}$. Вообще довольно показательно, как городская власть за короткий срок создает новое мемориальное пространство в Комсомольском сквере. Зеленых насаждений становится меньше. Их место занимает тротуарная плитка.

Как уже отмечалось, власть всеми силами стремится заполнить патриотический вакуум в общественном сознании и на ходу сконструировать новые мифы в русле Ельца как Города воинской славы. Открытие новых памятников затемняет подступающие проблемы, связанные с обслуживанием самих памятников и уходом за миметическим пространством. В условиях дефицита трудовых ресурсов и усложнения администрирования это превращается в настоящую головоломку.

Елец входит и в Ассоциацию малых туристских городов России. Власти, находясь в контексте исследований немецкого теоретика мемориальной культуры А. Ассман, пытаются использовать комбинаторику горячей и холодной памяти [Ассман, 2016]. Действительно, для искушенного ценителя русской провинциальной культуры, воплощающейся в Ельце, могут возникать проблемы правдоподобия, странного чередования реального и демонстрируемого. В частности, К. Паустовский, посещая в свое время Елец, писал, что не останавливался в гостинице. «Я был тогда слишком беден», - вспоминает русский классик [Паустовский, 1983, с. 227].

Идеологи городской администрации не особенно задумываются над проблемой смешивания эпох, хронологии, героических фигур и самих фактов. На наш взгляд, это происходит во многом и потому, что культурный текст создается не для озадаченной поисками исторической достоверности общественности. Объект посылов власти - «относительно непредвзятая аудитория» провинции, находящаяся в ситуации интеллектуального истощения [Скиперских, 2013, c. 27]. Куда более важным оказывается фактическое наполнение нового патриотического мемориала.

Нет сомнений, что такая спешка порождает ситуации эстетического диссонанса ввиду попытки связать прошлое с новыми трендами. Так произошло с памятником советскому художнику Н. Жукову, открытому в 2003 году. Сегодня творчество Жукова вполне вписывается в патриотический тренд. При подготовке к празднованию 9 Мая рассыпавшееся от времени основание памятника, которое в свое время было сделано из итальянского мрамора, обложили плиткой, имитирующей гвардейскую ленту. Власть посчитала эту меру адекватной тщательной реставрации и сохранению памятника в версии создателя - скульптора А. Таратынова.
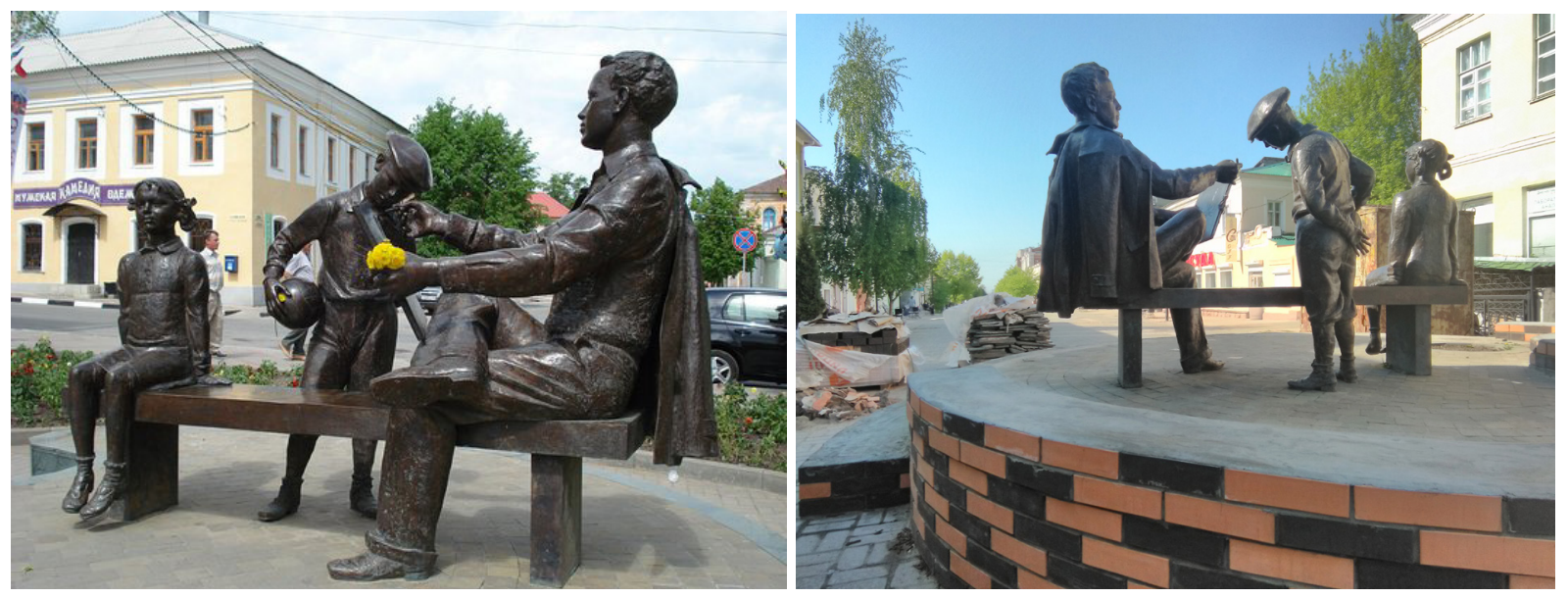

Рис. 1, 2. Реконструкция памятника Н. Жукову. Елец, май 2019 года

Источник: фото автора.

Новые акценты коммеморации в Ельце приводят к наполнению пространства новыми знаками, что, в принципе, характеризует официальную культуру, стремящуюся постоянно расширяться и углубляться. Власть не терпит пустоты, которая не пронизывается ее четкими сигналами. Отсюда любые попытки заполнения пустоты могут рассматриваться в контексте генерализации ее

10 Об открытии памятника М.А. Милорадовичу в Ельце и изобретенных патриотических контекстах см.: В Ельце появился памятник герою Отечественной войны 1812 года М.А. Милорадовичу, 01.09.2018/Администрация городского округа город Елец: https://elets-adm.ru/news/10819. 
влияния. Пропагандистский дискурс предполагает со стороны официальной культуры элементарное «занятие места. Чтобы другой не было» [Неизвестный, 1991, с. 38]. Поэтому в практиках коммеморации в провинциальном Ельце можно обнаружить некую методичность и тотальность. Вопрос целесообразности и эстетики оказывается вторичным по сравнению с необходимостью сиюминутной демонстрации торжественного момента открытия. Искушение запечатлеть себя в объективах камер оказывается выше необходимости поддержания исторической среды в надлежащем состоянии. Этот конфликт приводит к невразумительным наслоениям памяти, их гибридному, нелепому скрещиванию. Так, в начале июля в Ельце в рамках Пятого фестиваля малых городов в городском саду была открыта Аллея малых городов России с рядом металлических указателей. При этом самой властью постоянно подчеркивается аутентичность пространства городского бывшего дворянского - парка и уникального ботанического сада, о котором писали И. Бунин и М. Пришвин. Теперь установленные таблички соседствуют с чугунным фонтаном конца XIX века и известняковым гротом с беседкой и чашей фонтана, напоминающей контурами Черное море.

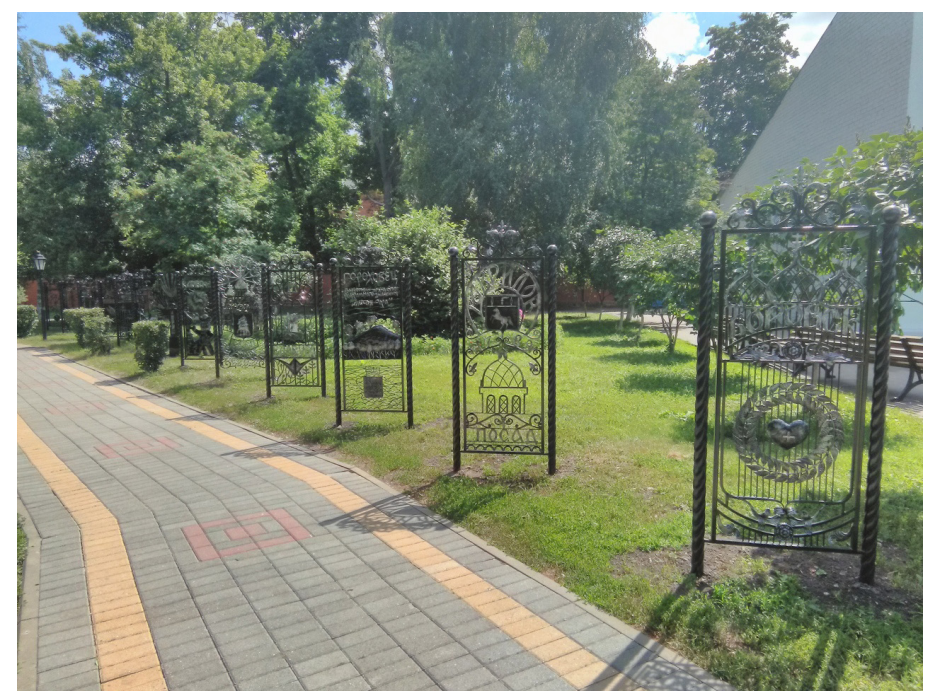

Рис. 3. Аллея малых городов в городском парке. Елец, июль 2019 года

Источник: фото автора.

Новые акценты коммеморации чувствуются и в новых линейках событийных мероприятий, начинающих проходить в Ельце и притягивающих к себе внимание не только областного центра, но и столицы. В процессе всех этих мероприятий происходит производство и закрепление в информационном пространстве региона образа Ельца как героического города-ратника, защищающего российскую государственность в драматические моменты истории. Все вышеприведенные случаи по-новому изобретаемых исторических событий являются подтверждением того, как Елец, следуя «Жизни Арсеньева», выступал оплотом Руси, «первым вдыхая бурю, пыль и хлад из-под грозных азиатских туч, то и дело заходивших над нею» [Бунин, 1989, с. 99].

К таким мероприятиям можно отнести рассчитанную на открытое сценическое пространство оперу на воде «Легенда о граде Ельце», посвященную героической обороне Ельца в период нашествия Тамерлана на Русь. В опере заняты московские актеры и музыканты, а местные реконструкторы и энтузиасты работают преимущественно в массовке ${ }^{11}$. Нужно отметить, что в связи с постоянным ростом числа проводимых мероприятий и постоянной сменой акцентов в исторических эпохах фактически существует дефицит исполнителей. Поэтому на миграцию провинциальных энтузиастов-реконструкторов из клуба в клуб, равно как и на смену эпох и периодов реконструкции, уже никто не обращает внимания.

Нечто подобное можно увидеть в мероприятии «Елецкий набат», реконструирующем события обороны Ельца в период московского похода гетмана Сагайдачного. Здесь мы снова мо-

11 Периодически можно слышать недоумение местных жителей по поводу достаточно высокой цены на билеты и сложности покупки самих билетов, распространяющихся через липецкие кассы и ориентированных на более состоятельных гостей Ельца, что определенным образом ущемляет интересы ельчан. 
жем увидеть попытку выделения специфической функции Ельца как защитника российской государственности ${ }^{12}$. Героическая функция Ельца, дополняющая его важную культурную миссию в регионе, подтверждается и в реконструкции Елецкой наступательной операции декабря 1941 года, являвшейся едва ли не ключевым этапом Битвы за Москву.

Все вышеприведенное показывает, как региональная и городская власть пытается нагрузить Елец новыми смыслами, раскрывающими привычную героику города, бытующую на уровне стертых метафор. Нет сомнений, что поддержание статуса культурной столицы Липецкой области требует постоянных синергетических усилий. С одной стороны, предельную концентрацию должна демонстрировать сама власть, с другой - необходима постоянная мобилизация городской общественности. Сравнивая нынешние практики культурной политики с советским опытом, можно отметить, что достаточно консервативная культурная политика при СССР не отличалась таким активным освоением городского пространства.

\section{Культурный ландшафт и его конструкторы: противоречия интерпретаций и политическая конъюнктура}

Практики закрепления за Ельцом неформального статуса культурного центра Липецкой области требуют активной поддержки не только со стороны администрации, но и широких общественных слоев, которые, как правило, следуют оценкам и позиции представителей интеллектуального сообщества. В определенной степени повествование от имени культурного центра осуществляется как интеллектуалами, поддерживающими власть, так и теми, кто ее критикует. В практиках наполнения городского пространства новыми мифами так или иначе присутствуют дискуссии. Интеллектуальный дискурс, оправдывающий статус Ельца как уникального культурного пространства, формируется с разных сторон - в зависимости от степени ангажированности самого субъекта, наполняющего его. В любом случае попытки формирования дискурса сами по себе автоматически являются политическими. Мишель Фуко отмечал, что интеллектуал, с одной стороны, зависит от системы капиталистического производства, но, с другой стороны, может раскрывать «истину тем, кто не мог ее сказать, и отсюда вся его совестливость и красноречие» [Фуко, 2002, с. 67].

Поэтому не представляется чем-то удивительным, когда конструирование нового мемориального пространства в Ельце, подчас парадоксально и нелепо воспринимающегося, происходит при поддержке лояльных интеллектуалов. Оправдательный дискурс новой культурной перезагрузки складывается из «тенденциозности, уверенно вносимой в историческое повествование», определенной французским исследователем Ж. Бенда в качестве свидетельства отклонения интеллектуала от своего предназначения [Бенда, 2009, с. 129]. Как правило, в моменты чересчур активного подключения местных интеллектуалов к тем или иным поворотам городской культурной политики становится очевидна их политическая ангажированность.

Впрочем, данные усилия не всегда эффективны. Как нами уже отмечалось в предыдущих исследованиях культурного пространства города, попытки воздействовать «сверху» с помощью патриотических клише, «выступают серьезным раздражителем „на выходе“» и «создают основание для недовольства и мягкого сопротивления» [Скиперских, 2013, c. 27].

Провинциальные интеллектуалы могут постепенно вставать по разные стороны баррикад. Важным условием выбора стратегии сосуществования с властью является степень прямой зависимости от нее. И если в случае учителей, университетских преподавателей и работников сферы культуры не возникает сомнений в преданности политическому курсу, то на тех, кто не так очевидно зависит от бюджета, уже сложнее воздействовать. Тем не менее власть по-прежнему может оказать определенное давление на частный сектор. В Ельце есть ряд частных музеев и галерей, владельцы которых так или иначе могут оказываться зависимыми от городской власти, а по ряду проектов и непосредственно взаимодействовать с администрацией. Интересно, что количество частных музеев и галерей, работающих «по предварительному звонку», уже превосходит то, что находится под контролем муниципалитета.

Наконец, лояльным, подпевающим власти голосам могут противостоять другие акторы со сложившейся репутацией краеведов и хранителей уникального исторического и культурного наследия города. Но и они, как правило, не заинтересованы в конфронтации, скрепя сердце

12 Подробнее о мероприятии см.: «Елецкий набат» прозвучит во второй раз: войска гетмана Сагайдачного вновь будут штурмовать елецкую крепость, 21.06.2019/Администрация городского округа город Елец: https://elets-adm.ru/news/13120. 
принимают культурную перезагрузку. Максимум, что они могут сделать, - повлиять на отдельные сегменты культуры ради сохранения аутентичности и неповторимого стиля города. Тем не менее представляется очевидным разрыв между официальной демонстрацией Ельца как пространства постоянного праздника и туристических событий по самым разным поводам и другими, более интимными и частными, практиками работы с городским текстом.

Если политика власти подвержена турбулентным интересам, то противостоящее ей видение интеллектуальной общественности исходит из стратегического и просчитанного будущего Ельца. Возможно, проблема скрывается и в различиях технократической культуры. Зачастую среди оппонирующих власти интеллектуалов оказываются бывшие чиновники, деятельность которых была связана с развитием культурного пространства Ельца в период СССР и ранних 1990-х. По мнению В. Глазычева, внимание к проблемам стратегического развития городских пространств как раз находится «исключительно в кругу специалистов, тесно связанных с прежней системой управления. Эти специалисты с чрезвычайным трудом адаптировались к идеологемам рыночной экономики, на годы ставших господствующими, и потому уже оказались на дальней периферии дискуссий либо выпали из них полностью» [Глазычев, 2011, с. 195].

Таким образом, разработка мифа о культурной столице липецкого края происходит параллельными курсами, где движутся региональная и городская власть с лояльными интеллектуалами, с одной стороны, и целый ряд альтернативных акторов, не включенных в какие-либо управляемые сверху институции, - с другой. При этом альтернативные акторы формируют свой образ культурного центра, равно как и язык его описания. Оба дискурса, совпадая по целеполаганию, могут не совпадать по структуре и способам конструирования. Альтернативными субъектами могут выступать харизматические одиночки из краеведов, киноведы, частные галеристы и экскурсоводы, представители блогосферы и интеллектуалы, в силу каких-либо обстоятельств оказавшиеся в других городах и странах, но пристально наблюдающие за производством культурного текста Ельца. Показательно, что из процесса альтернативного описания Ельца как уникального культурного объекта выключились местные университетские интеллектуалы. В международных Бунинских конференциях начала 1990-х годов участвовали виднейшие специалисты со всего мира и владельцы парижских архивов русской эмиграции. Совершенно неслучайно, что развитие университета в Ельце происходило в бунинской матрице, а сам вуз в 2000 году получил имя нобелевского лауреата. Однако в современной России любая альтернативная деятельность тесно связана с политикой, и в условиях провинции становится опасным подчеркивать культурное инакомыслие. Если университетские преподаватели как-то участвуют в городской культурной политике, то на стороне администрации, подчеркивая тем самым достаточно незавидное и подчиненное положение маленьких провинциальных университетов.

В 2018 году в Ельце появились активисты движения «Том Сойер Фест», занимающегося сохранением историко-культурной среды российских городов. Энтузиасты, озабоченные состоянием городских зданий, пытаются создать некие альтернативные формы действия, мотивы которых можно объяснить, обращаясь к Г. Башляру, однажды отметившемуся признанием «в собственной топофилии» [Башляр, 2004, с. 22].

Именно благодаря их усилиям в городе был частично восстановлен участок аутентичного мощения тротуаров известняковыми плитами. Символично, что это было сделано напротив бывшей мужской гимназии, где учились И. Бунин и М. Пришвин, где преподавал В. Розанов. Деятельность энтузиастов по восстановлению среды с регулярными обращениями в адрес всех вышестоящих инстанций тормозила сроки реконструкции. Постепенно администрация города была втянута в переговорный процесс с Управлением по охране объектов культурного наследия Липецкой области и активистами движения, в результате чего пришлось пойти на небольшие уступки по принципу «не помогать и не мешать».

Столкновения городской общественности с властью по поводу сохранения исторической среды случались в городе и значительно раньше. В частности, В. Турбин пишет о том, что еще в 1960-е годы городские интеллектуалы «пытались организовать на охрану архитектурных памятников школьников и молодежь...» [Турбин, 1967, с. 28]. Уже позже важное место в сохранении культурного ландшафта города занимала деятельность клуба «Вече», сделавшего целый ряд значимых для Ельца краеведческих открытий и препятствовавшего политике властей по унификации культурного наследия города в соответствии с текущим политическим моментом. 
Эстетический диссонанс приводит подчас к парадоксальным последствиям. Примером может служить попытка реконструкции городских тротуаров, вскрытых во время ремонта ряда центральных улиц летом 2018 года. Активистам «Том Сойер Феста» удалось отстоять часть одной улицы и выполнить работы своими силами. Однако более масштабный проект 2019 года, требовавший куда более значительных сил со стороны энтузиастов, привел к совершенно нелепому, антиэстетическому решению. К проекту неравнодушных городских жителей присоединились достаточно известные в городе фигуры, но другие предпочли остаться в тени и не показываться на глаза администрации.

Городскую власть часто упрекают в антиэстетизме, причина которого в дистанцировании от процесса интеллектуальных сил сообщества. Возможно, именно подобный подход со стороны городской администрации стал предметом критики врио Липецкой области И. Артамонова, периодически инспектировавшего елецкие стройки. Главу города Сергея Панова тогда упрекали в том, что в Ельце якобы «все делают по-деревенски» ${ }^{13}$. Видимо, это и послужило причиной смены главы Ельца в июле 2019 года, когда вместо Панова был назначен Евгений Боровских. Как раз в тот момент, готовясь к губернаторской кампании, И. Артамонов поменял ряд глав муниципалитетов. Назначение Боровских имело еще и гипотетические цели культурного преображения города, поиска сюжетов, позволяющих по-новому представить городское пространство. Замысел состоял в том, что молодой политик (пусть и «варяг») лучше справится с этой задачей, нежели прежний мэр, являющийся заложником консервативной среды и длительное время не обновлявший администрацию ${ }^{14}$.

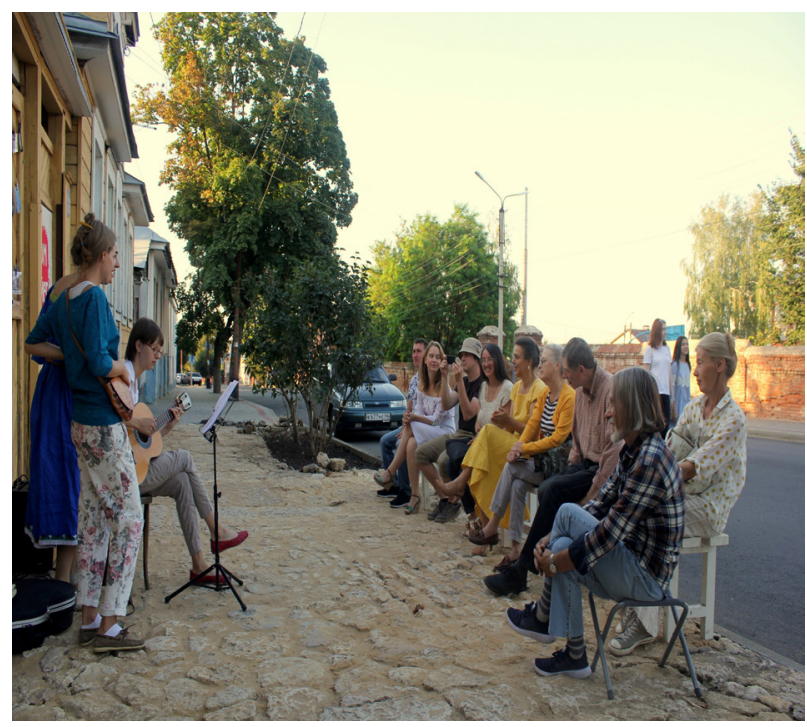

Рис. 4. Завершение сезона реконструкции. Частная инициатива без поддержки администрации. Дом Новосельцевых. Елец, 2018 год

Источник: фото автора.

13 Оценка врио главы Липецкой области тогда не казалась наигранной. См.: Игорь Артамонов о ходе работ в сквере Харченко: «Все по-деревенски делаете, все тут отдает деревней» (https://vk.com/video-74441888_456243833).

14 Отчасти, видимо, по этой причине в ноябре 2019 года в городе в течение недели проходили мероприятия с участием руководителей и слушателей международного образовательного проекта «РЕ-школа», собиравших информацию о городской среде и пытавшихся организовать дискуссии по поводу будущего культурного наследия среди горожан. Встреча «РЕ-школы» с горожанами была проведена и в феврале 2020 года в ЕГУ им. И.А. Бунина. В ноябре 2019 года в Елец приезжал известный дизайнер Артемий Лебедев. Студия Лебедева, возможно, будет разрабатывать бренд для города. По оценке близких к администрации города информантов, в приезде А. Лебедева был заинтересован лично глава Ельца Е. Боровских, а самым убедительным аргументом в пользу присутствия в городе в качестве потенциального заказчика муниципальной власти являлась его узнаваемость в информационном пространстве, опыт действующих проектов, большое количество подписчиков его пабликов и т.д. 


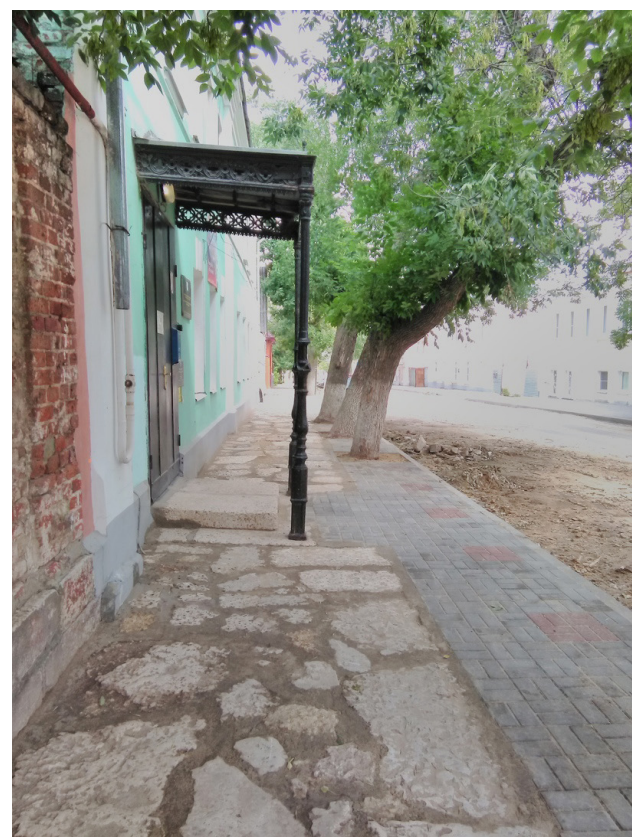

Рис. 5. Реконструкция мостовой. Комбинация известняковых плит и современной плитки. Патронат городской администрации. Елец, 2019 год

Источник: фото автора.

\section{Сохранить нельзя разрушить: культурная среда и политика городской власти}

Приведенные выше примеры показывают, что за уникальную городскую среду сражаются преимущественно индивидуальные акторы. Их ресурсы ограниченны, и самое большее, что они могут сделать, - это максимально распространить информацию о надвигающихся рисках, о трагической реальности, в которую погружена российская провинция, убедительной метафорой которой выступает Елец. Блогосфера может выступить спасительной площадкой, в рамках которой активисты могут заручиться поддержкой участливых симпатизантов. Деятельность альтернативных акторов не может принести городской и региональной администрации каких-то очевидных дивидендов. «Другой», уходящий Елец, проступающий в эмоциональных текстах альтернативных акторов, не может не отразиться на репутации правящего класса региона и города.

Восприятие Ельца как культурного центра приобрело негативные коннотации после публикации Ильи Варламова о судьбе протестантской кирхи, с согласия городской администрации переделанной под магазин стройматериалов.

Вместе с тем в городе остается достаточно много объектов, выступающих хранителями уникальных культурных текстов и погибающих буквально на глазах.

Только за 2019 год в Ельце разрушилось сразу нескольких важных объектов, создающих ощущение уникального культурного поля русской провинции конца XIX века. Такое ощущение, что утрачивание архитектурной среды происходит по нарастающей, и с каждым месяцем возникают все новые и новые прорехи в ткани города. Только по улице Октябрьской, в считаных метрах от городской администрации, весной 2019 года произошло обрушение фрагмента стены на одном историческом здании. Спустя несколько дней уже в другом месте порыв ветра сорвал практически всю крышу с другой постройки, относящейся к концу XIX века.

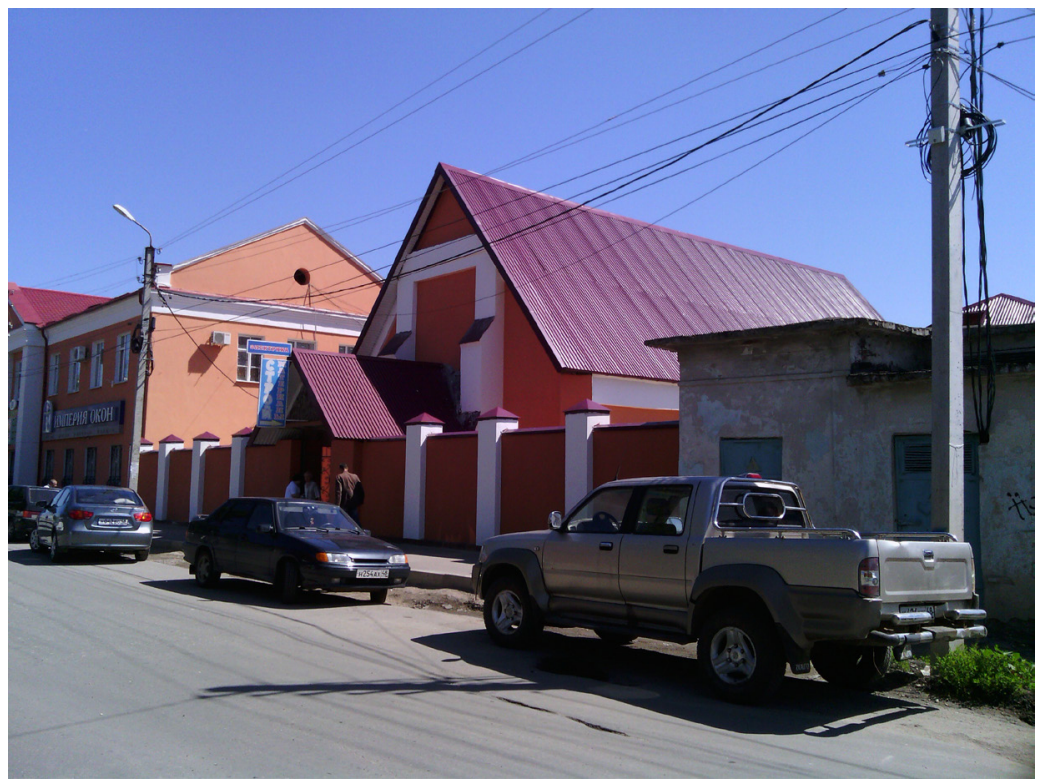

Рис. 6. Елец. Протестантская кирха сегодня

Источник: фото автора. 


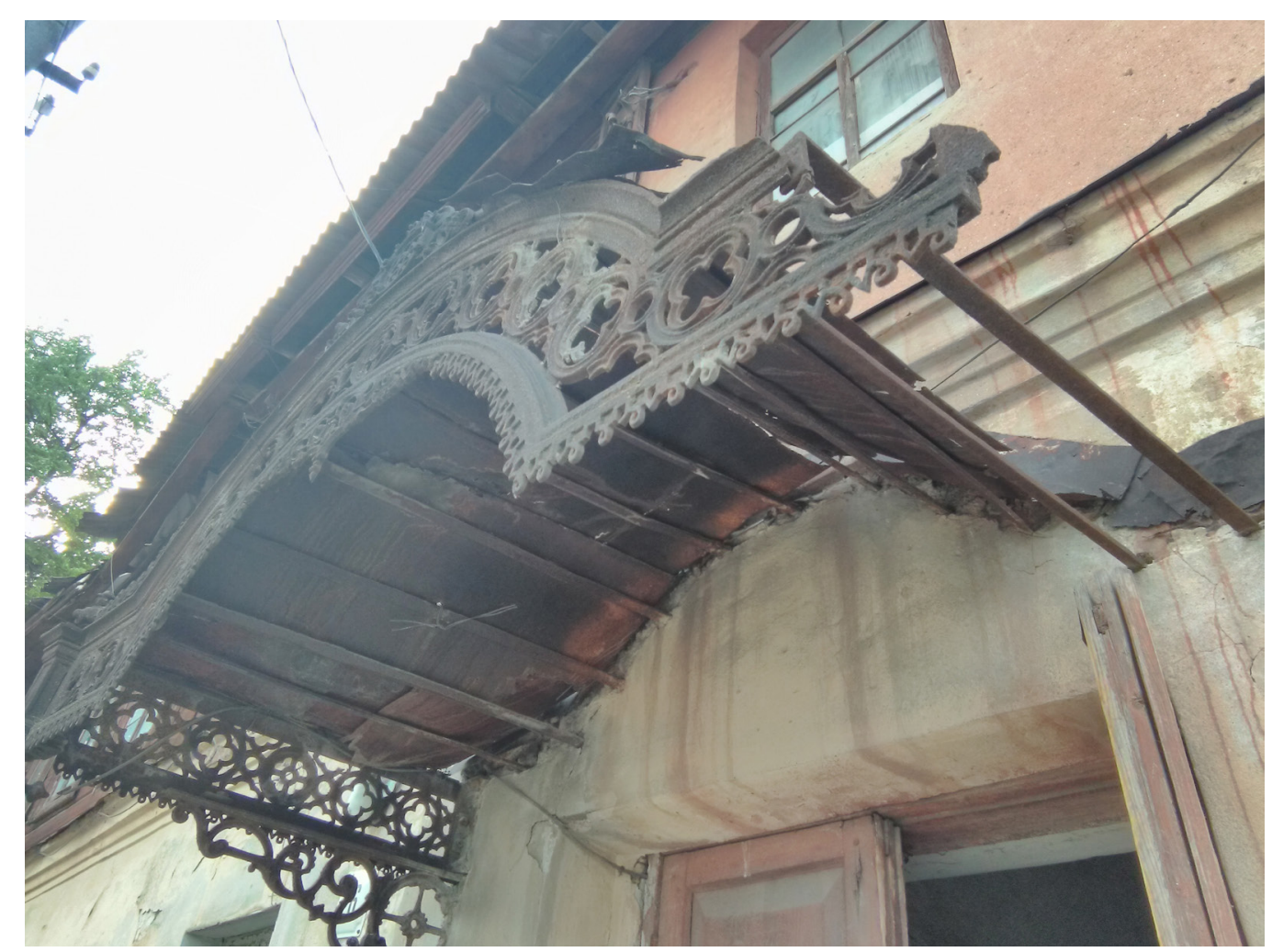

Рис. 7. Май 2019 года. Чугунное крыльцо бывшего дома нотариуса Барченко

Источник: фото автора.

Весной 2019 года произошло обрушение Владимирской церкви в Черной слободе, роспись наружных стен которой приписывали французам, оставшимся в России после Отечественной войны 1812 года. Исследователи отмечают особую лепную работу, как будто перекликающуюся с творчеством елецких кружевниц, «повторяющих движение тонких линий кружев» [Клоков, Найденов, Новосельцев, 2006, с. 234]. Рядом с Владимирской церковью квартировался русский религиозный философ В. Розанов, для которого елецкий этнопейзаж, безусловно, центрировался городскими храмами. Среди храмов мог доминировать именно тот объект, который возвышался над одним из его елецких адресов. Обрушение Владимирской церкви совпало по времени с трагедией Нотр-Дама. Местная общественность и патриотически ориентированные сообщества были возмущены демонстрацией сострадания французской трагедии со стороны россиян на фоне как будто невидимой елецкой потери.

Утрата среды происходит и в связи с другими объектами городской архитектуры. Сегодня едва ли не каждое здание в городе может таить в себе серьезнейшую угрозу для безопасности прохожих. Наверное, наиболее выделяющимся из них является огромное здание бывшей табачной фабрики, занимающее целый квартал в самом центре Ельца. Нынешнее состояние исторического объекта говорит о серьезных проблемах в организации архитектурной, культурной и экономической политики муниципалитета, равно как и об эстетических горизонтах отдельных политиков, принимающих решения.

Можно с сожалением констатировать едва ли не ежедневное ухудшение состояния исторических зданий, составляющих практически весь центр города. На наш взгляд, подобное только подтверждает несовпадение оценки потенциала Ельца в глазах власти и заинтересованной общественности.

Вместе с тем в последние несколько лет происходят события, заставляющие убеждаться в переключении акцентов культурной политики на Липецк, городской текст которого насыщается событиями, традиционно связывавшимися с Ельцом. 

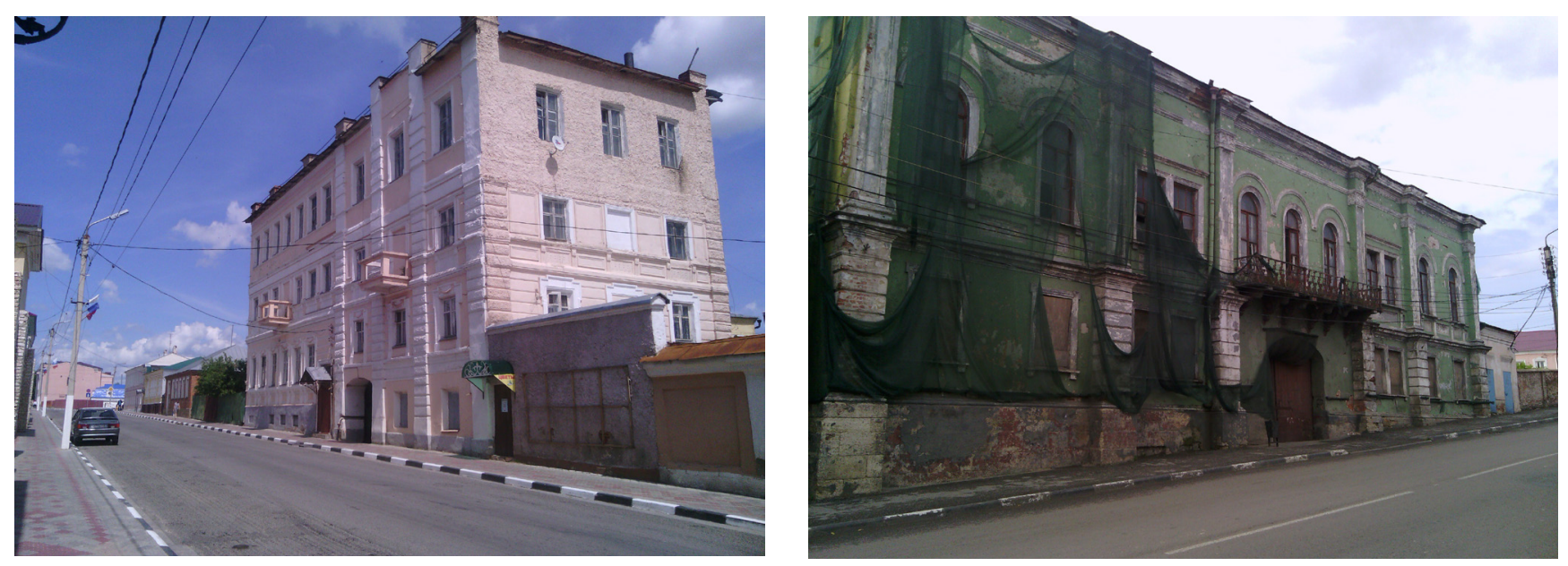

Рис. 8, 9. Разрушающиеся здания в центре Ельца, 2015 год

Источник: фото автора.

Постоянное выяснение условий функционирования собственной культурной институции приводит к тому, что в Липецк перемещаются важные для Ельца мероприятия. В частности, приобрел липецкую прописку музыкальный фестиваль Тихона Хренникова, с момента своего создания проводившийся в Ельце. На первом таком фестивале было весьма многолюдно, собравшейся публике представлял свое мастерство Валерий Гергиев. Решается вопрос о переносе в Липецк некоторых отделений училища искусств. Проблемы с использованием огромного культурного потенциала сказываются и на стремлении частных предприятий не связывать свою дальнейшую судьбу с Ельцом. Так, знакомые галеристы в беседе с автором признались, что всерьез подумывают о переносе своего бизнеса в Липецк - художественной галереи, магазинов, багетной мастерской. В настроении других представителей культурной сферы ощущается такая же обреченность, хотя и постоянно подчеркивается любовь к малой родине.

Показательно, что 18 июля 2019 года в городском парке Ельца на большом экране транслировался концерт из Липецка, посвященный Дню металлурга. Ельчане видели звезд отечественной эстрады, поздравлявших липецких сталеваров. Демонстрацию в Ельце данного мероприятия сложно назвать сколько-нибудь логичной. Как часто происходит, концерт был «рекомендуем» к посещению работниками бюджетной сферы. Этот и другие примеры говорят о проявлениях реваншизма областного центра в отношении Ельца и постепенного включения жителей города в культурный контекст Липецка.

\section{Выводы}

Уникальная среда Ельца, испытывающего мучительную концептуализацию - не центр, но и не периферия (учитывая самодостаточный культурный бэкграунд), может оказаться утраченной вместе с фактическим состоянием города как субъекта культуры. Провинциальный мир выглядит для него тесным и излишне агрессивным с точки зрения критической рефлексии. Необходимость постоянного общения с бюрократической машиной организации какихлибо мероприятий является губительной для творческих людей. Поэтому не кажется удивительным, что город интеллектуально пустеет. Все больше образованной молодежи выбирает траектории развития, не связанные с Ельцом. Перспектива падения уровня культурного и социального капитала локуса представляется весьма вероятной. Так, А. Гарбуз приводит пример молодых интеллектуалов, вынужденных организовывать выставку в Липецке из-за невозможности ее проведения в Ельце [Гарбуз, 2014].

Миграция из города интеллектуальных ресурсов наряду с экономическими причинами имеет и несомненные культурные основания. В крупных городах оказывается проще реализовать свои культурные проекты и получить достойное вознаграждение. Эта объективная мотивация выталкивает из Ельца молодых фотографов, видеографов, журналистов, танцоров, блогеров. Креативная молодежь, как нам представляется, тяготится той атмосферой, в которую 
погружена сегодня российская провинция. В Москве сосредоточены тысячи выпускников ЕГУ им. И.А. Бунина, работающие школьными учителями, частными воспитателями, юристами, экономистами, менеджерами; многие приезжают в столицу работать вахтовым способом даже не по специальности. В последнее время участились случаи отъезда из города перспективных спортсменов. Впоследствии оказывается, что они выступают на престижных соревнованиях, никак не обозначая свою связь с Ельцом и Липецкой областью.

Городской власти необходимо понять, что именно эти люди как раз могли бы удерживать город в орбите мифа о культурном центре Липецкой области и способствовать укоренению патриотических ориентаций, связи с историей, малой родиной, памятью предков. К сожалению, нельзя сказать, что городская администрация предлагает какие-либо проекты и программы, создающие мотивацию присутствия в Ельце тех, кто своим потенциалом может способствовать репродукции культуры и созданию важных для современного города текстов, конструирующих его прошлое, настоящее и будущее.

Вплоть до настоящего времени не совсем ясно, какой посыл исходит от городской власти и кто именно является аудиторией, получающей сообщение о Ельце как уникальном пространстве, инвестиции в которое стратегически оправданны как со стороны федерального бюджета, так и со стороны частных инвесторов. Адресат не установлен сколько-нибудь очевидно. С кем выстраивается коммуникация городской власти? С политическими и властными структурами различных уровней, бизнес-структурами, экспертным сообществом и СМИ, наконец, жителями города и других регионов, городов и стран, прежде всего молодежью и высококвалифицированными специалистами? Именно эти группы в качестве целевой аудитории выделяются некоторыми исследователями [Люлько, 2011, с. 72].

Однако, несмотря на имеющиеся проблемы, культурное пространство Ельца выглядит в большей степени интересным и насыщенным различными легендами и мифами, нежели других муниципалитетов Липецкой области. Но практики работы с культурным пространством Ельца, видимо, ограничиваются рамками провинциального менталитета, не отличающегося амбициозностью и радикальными подходами по генерации новых идей и смыслов, которые позволяют отдельно взятой истории некоторое время находиться в новостных топах, а может быть, и на долгое время стать образцами для подражания и благодарной рецепции.

\section{Источники}

Абашев В. (2000) Пермь как текст. Пермь в русской культуре и литературе XX века. Пермь: Изд-во Пермского университета.

Ассман А. (2016) Новое недовольство мемориальной культурой. М.: Новое литературное обозрение.

Барт Р. (1989) Избранные работы. Семиотика. Поэтика. М.: Прогресс, Универс.

Башляр Г. (2004) Избранное: поэтика пространства. М.: РОССПЭН.

Бенда Ж. (2009) Предательство интеллектуалов. М.: ИРИСЭН, Социум.

Богомяков В. (2007) Региональная идентичность «земли тюменской»: мифы и дискурс. Екатеринбург: Издательский дом «Дискурс-Пи».

Бунин И. (1989) Жизнь Арсеньева. Повести и рассказы. М.: Правда.

Гарбуз А.А. (2014) «Хоздвор» в Липецке: манифестации протестного искусства в российской провинции //Теории и проблемы политических исследований. № 4. С. 14-26.

Глазычев В.Л. (2011) Город без границ. М.: Территория будущего.

Дебор Г. (2011) Общество спектакля. М.: Опустошитель.

Дмитриев А.В. (2007) «Я вырос среди народа...». Липецкий край в жизни и творчестве И.А. Бунина. Липецк: Ориус.

Дука А.В. (2016) Российский город как политическое пространство//Современный город: власть, управление, экономика. № 1. С. 9-21.

Журавлева Н.И., Мельникова С.В. (2016) Екатеринбург: между столичностью и провинциальностью. Современный город: власть, управление, экономика. № 1. С. 219-229.

Завалипина М., Литаврин С. (2019) Туризм - новый шанс для городов и сел//Регион. Вести. № 27 (443).

Кистерева Н., Резвый В. (2017) Счастье покоя. Стихотворения и переводы. М.: Водолей.

Клоков А.Ю., Найденов А.А., Новосельцев А.В. (2006) Храмы и монастыри Липецкой и Елецкой епархии. Елец. Липецк: Липецкое областное краеведческое общество. 
Краснова Т.В. (2008) Елецкое кружево (этнографический комментарий к текстам И.А. Бунина). Бунинская Россия: Елец. Выпуск 3. Елец: ЕГУ им. И.А. Бунина.

Липецкая земля. Календарь событий 2019 г. (2019) Липецк: Областной центр событийного туризма.

Люлько А.Н. (2011) Имидж города и факторы, влияющие на его формирование//Власть. № 8. С. $71-73$.

Манин В.С. (1999) Искусство в резервации. Художественная жизнь России 1917-1941 гг. М.: Эдиториал УРСС.

Мальковская И.А. (2004) Знак коммуникации. Дискурсивные матрицы. М.: Эдиториал УРСС.

Неизвестный Э. (1991) Говорит Неизвестный. Пермь: Пермские новости.

Паустовский К. (1983) Золотая роза. М.: Детская литература.

Ридингер Н.А. (1993) Материалы для истории и статистики г. Ельца. Елец: Елецкие куранты.

Сартори Д. (2003) Искажение концептов в сравнительной политологии//Политические исследования. № 4. С. $152-161$.

Скиперских А.В. (2017) История российской провинции в мемориальной культуре: политическое конструирование//Вестник Томского государственного университета. История. № 47. С. 121-127.

Скиперских А.В. (2013) Политический протест в российской провинции: структура, динамика, перформансы (на примере Липецкой области). Липецк: Гравис.

Тулинова О.В. (2012) Елец музыкальный. Становление и развитие музыкального образования в г. Ельце: традиции и современность. Елец: ЕГУ им. И.А. Бунина.

Турбин В. (1967) Недавно, в XIV столетии. Огонек. № 16. С. 28-29.

Фуко М. (2002) Интеллектуалы и власть. Избранные политические статьи, выступления и интервью. М.: Праксис. Широков А.М. (1994) Ностальгия по училищу. Елецкая быль. Краеведческий сборник. Выпуск второй. Липецк: Ориус.

Molotch H. (1976) The City as a Growth Machine: Toward a Political Economy of Place//American Journal of Sociology. Vol 82. No 2. P. 309-332. 


\section{ALEKSANDR SKIPERSKIKH YELETS IN A REGIONAL CULTURAL SPACE: PROVINCE OR CENTER?}

Aleksandr V. Skiperskikh, Doctor of Political Science, Professor, Department of Philosophy and Social Science, Bunin Yelets State University; 28, Kommunarov str., Yelets, 399770, Russian Federation; tel.: +7 4746722193

E-mail: pisatels@mail.ru

\section{Abstract}

This article assesses the possibilities of the city Yelets being considered as the cultural center of the Lipetsk region. Having the status of a 'city of military glory' and a rich cultural and industrial history, its heroic character, which preserved Yelets in the discourse of intellectual history, and left the memory of the city in important Russian texts all seem to support this point of view. However, a number of factors may impede such a positioning of the urban space. The rivalry with Lipetsk for tourist flows influences this and is gradually being actualized in the new economic and cultural reality, where culture is the driver of development. The article uses discourse analysis to determine the concept of 'center' among subjects of urban policy.

Key words: center; cultural policy; discourse; Lipetsk region; space; province; Yelets

Citation: Skiperskikh A.V. (2019) Yelets in a regional cultural space: province or center? Urban Studies and Practices, vol. 4, no 3, pp. 71-88 (in Russian). DOI: https://doi.org/10.17323/usp43201971-88

\section{References}

Abashev V. (2000) Perm` kaktekst. Perm`v russkojkul`turei literature XX veka [Perm as text. Perm in Russian culture and literature in XX century]. Perm: Izd-vo Permskogo universiteta. (in Russian)

Assman A. Novoe nedovol'stvo memoreal'noj kul'turoj [New dissatisfaction of memorial culture]. Moscow: Novoe literaturnoe obozrenie. (in Russian)

Bart R. (1989) Izbrannye raboty. Semiotika. Poehtika [Selected works. Semiotics. Poetics]. Moscow: Progress. Univers. (in Russian)

Bashliar G. (2004) Izbrannoye: poetika prostranstva [Favorities: poetics of space]. Moscow: Rosspen. (in Russian)

Benda Zh. (2009) Predatel’stvo intellektualov [Betrayal of intellectuals]. Moscow: Irisen, Sotsium. (in Russian)

Bogomyakov V. (2007) Regional’naya identichnost` «zemli tyumenskoy»: mify I diskurs [Regional identity of the «land of Tyumen»: myths and discourse]. Ekaterinburg: Diskurs-Pi. (in Russian)

Bunin I. (1989) Zhizn`Arsen`eva. Povest i irasskazy [Arsenyev`s Life. Stories]. Moscow: Pravda. (in Russian)

Debor G. (2011) Obshchestvospektaklia [The Society of the Spectacle]. Moscow: Opustoshitel'. (in Russian)

Dmitriev A.V. (2007) Ya vyros sredi naroda. Lipetskiy kray v zhizni i tvorchestve I.A.Bunina [I grew up among the people. Lipetsk region in the life and work of I.A. Bunin]. Lipetsk: Orius. (in Russian)

Duka A.V. (2016) Rossijskij gorod kak politicheskoe prostranstvo [Russian city as a political space]. Sovremennyy gorod: vlast , upravleniye, ekonomika [Modern City: Power, Management, Economy], vol. 1, pp. 9-21. (in Russian)

Foucault M. (2002) Intellektualy i vlast’. Izbrannye politicheskie stat’l, vystupleniya i interv yu [Intellectuals and Power. Selected Articles, Speeches and Interviews]. Moscow: Praksis. (in Russian)

Garbuz A.A. (2014) «Khozdvor» v Lipetske: manifestatsii protestnogo iskusstva v rossiyskoy provintsii [«Hozdvor» in Lipetsk: demonstrations of protest art in the Russian province]. Teorii i problemy politicheskih issledovaniy [Theories and Problems of Political Studies], no 4,pp. 14-26. (in Russian)

Glazychev V.L. (2011) Gorod bez granits [The City Without Borders]. Moscow: Territoriia budushchego. (in Russian)

Kistereva N., Rezvyy V. (2017) Schast ye pokoya. Stihotvoreniya i perevody [Happiness of peace. Poems and translations]. Moscow: Vodoley. (in Russian)

Klokov A.Yu., Najdenov A.A., Novosel’tsev A.V. (2006) Khramy i monastyri Lipetskoj i Yeletskoj yeparkhii [Temples and Monasteries of the Lipetsk and Yelets Diocese]. Yelets. Lipetsk: Lipetskoe oblastnoe kraevedcheskoe obtshestvo. (in Russian) 
Krasnova T.V. (2008) Yeletskoe kruzhevo: yetnograficheskiy kommentariy k tekstam I.A. Bunina [Yelets lace: ethnographic commentary on texts of I.A. Bunin]. Yelets: EHU im. I.A. Bunina. (in Russian)

Lipetskaya zemlya. Kalendar’ sobytiy 2019 g. (2019) [Lipetsk earth. Calendar of events 2019]. Lipetsk: Oblastnoj tsentr sobytiynogo turizma. (in Russian)

Lyul `ko A.N. (2011) Imidzh goroda i factory, vliyayushchie na yego formirovaniye [The image of the city and the factors influencing its formation]. Vlast ' 'Power], no 8. pp. 71-73. (in Russian)

Mal’kovskaya I.A. (2004) Znak kommunikatsii. Diskursivnyye matritsy [Communication sign. Discursive Matrices]. Moscow: Editorial URSS. (in Russian)

Manin V.S. (1999) Iskusstvo v rezervatsii. Khudozhestvennaya zhizn` Rossii 1917-1941 gg. [Art in the Reservation. Artistic Life of Russia 1917-1941]. Moscow: Editorial URSS. (in Russian)

Molotch H. (1976) The City as a Growth Machine: Toward a Political Economy of Place. American Journal of Sociology, vol. 82, no 2. pp. 309-332.

Neizvestnyy E. (1991) Govorit Neizvestnyy [Neizvestny says]. Perm: Permskie novosti. (in Russian)

Paustovsky K. (1983) Zolotaya roza [Golden Rose]. Moscow: Detskaya literature. (in Russian)

Ridinger N.A. (1993) Materialy dlya istorii i statistiki g. Yel’tsa [Materials for the history and statistics of Yelets]. Yelets: Yeletskiye kuranty. (in Russian)

Sartori D. (2003) Iskazhenie kontseptov v sravnitel'noi politologii [Distortion of concepts in comparative political science]. Politicheskie issledovaniya [Political Studies], no 4.pp.152-161. (in Russian)

Shirokov A.M. (1994) Nostal'giya po uchilishchu [Nostalgia for school] Yeletskaya byl : Kraevedcheskiy sbornik [Yelets Story. Local History Collection]. Lipetsk: Orius, vol. 2, pp. 12-16. (in Russian)

Skiperskikh A.V. (2017) Istoriya rossijskoj provintsii v memorial ’noj culture: politicheskoe konstruirovanie [History of Russian Province in the memorial culture: political construction]. Vestnik Tomskogo Gosudarstvennogo Universiteta. Istoriya [Journal of Tomsk State University. History], no 47. pp. 121-127. (in Russian)

Skiperskikh A.V. (2013) Politicheskiy protest v rossijskoj provintsii: struktura, dinamika, performansy (na primere Lipetskoy oblasti) [Political Protest in the Russian Province: structure, dynamic, performances (on the Example of the Lipetsk Region)]. Lipetsk: Gravis. (in Russian)

Turbin V. (1967) Nedavno, v XIV stoletii [Recently, in the XIVth century]. Ogonok [Light], no 16, pp. 28-29. (in Russian)

Tulinova O.V. (2012) Yelets muzykal’nyy. Stanovleniye i razvitiye muzykal’nogo obrazovaniya v Yel’tse: traditsii i sovremennost' [Yelets Musical. Formation and Development of Music Education in Yelets: Tradition and Modernity]. Yelets: EHU im. I.A. Bunina. (in Russian)

Zavalipina M., Litavrin S. (2019) Turizm - novuy shans dlya gorodov i sel [Turism as a new chance for cities and villages]. Region. Vesti. [Region. News], no 27 (443). (in Russian)

Zhuravleva N.I., Melnikova S.V. (2016) Ekaterinburg: mezhdu stolichnost yu i provintsial ’nost yu [Ekaterinburg: Modern City: Power, Management, Economy]. Sovremennyy gorod: vlast ; upravleniye, ekonomika [Modern City: between metropolitan and provincial], vol. 1, pp. 219-229. (in Russian) 